\title{
WEED CONTROL TECHNOLOGY ON SOYBEAN CROPS \\ IN THE CONDITOIN OF "AGRIFAS" COMPANY LTD \\ BILOPILLIA DISTRICT SUMY REGION
}

\section{Shokun Oleksandr ${ }^{1}$ Ishchenko Oksana ${ }^{2}$}

DOI: https://doi.org/10.30525/978-9934-571-89-3_112

Soil-climatic conditions of Ukraine mainly contribute to the cultivation of soybeans. The production of soybeans in our country is rather increase which connects with the development of livestock, poultry farmingand significant expansion of nutrition of this crop. In Ukraine, in terms of crop area (more than 2 million hectares), soybeans have entered the first ten most common crops, and with the dynamics of growth surely holds leadership. Soybeans in the beginning of vegetation grow relatively slowly and weeds compete with it for the consumption of moisture, nutrients, and the use of light. This leads to its low competitiveness in comparison with weeds. Weed yields from weeds can range from 30 to $50 \%$. Therefore, the integrated control of weeds is of paramount importance for the successful cultivation of soybeans. In recent years, the problem of protection against weeds has become much worse due to the deterioration of the financial and economic condition of farms, lost to $20 \%$ of products, to protect from weeds accounts for one third of the costs of growing crops.

In "Agrifas" Company Bilopillia District Sumy Region we have been researching the effectiveness of herbicides influences on soybeans sowings since 2017 and develop the weed control technology. During this period on soybeans sowings the following types of weed have been revealed: nontrab plain, loboda white, sirens common, mouse blue, millet chicken, thistle pink, pirate creeping. The research was conducted according to the generally accepted methodology. Weed accounting was carried out quantitatively by weight method, since this method is the best for obtaining full information about actual crop infestation. The number of weeds was determined directly by counting their stems on trial sites, selected using a frame with a ratio of width to a length of 1:1. The mass of all above-ground organs of plants was expressed in grams per unit area. It is characterized by three quantities: the mass of living plants (crude mass), their absolute dry mass and the mass of plants in the airdry state. The most accurate estimation of indigestion of crops will be when simultaneously determine both the number and mass of weeds. For this purpose, from a site limited by a frame, we chose weeds and placed them in cellophane bags in order to prevent plants from drying out. In the laboratory, the weeds were spread out by species or groups, counting their number, cut off at the level of the root neck of the roots that was preserved, and weighed.

\footnotetext{
${ }^{1}$ Sumy National Agrarian University, Ukraine

${ }^{2}$ Sumy National Agrarian University, Ukraine 
Our experiment includes the following scheme: 1. Control (without spraying with herbicides); 2. Spraying Dual Gold 960 EC, k.e., 1,6 1 / ha + Basagran, cf., 2,5 1 / ha (standard); 3. Spraying Gesagard 500 FW, hp, 3.01 / ha + Harmony 75, inc., 8 g / ha (experiment). During the counting on the control in 2017, the following number of weeds was detected: - one-year-old one-day eaters - 23, one-year two-eggplants - 64, perennial grasses-1, perennial two-eggplants - 2. At spraying Dual Gold 960 EC + Bazahran (standard) in 2017 were found the following number of weeds: - annual odnosim'yadolni - 5-year dvosim'yadolni -8 , perennial crops -1 Long dvosim'yadolni -2 . When spraying Chystets 500 FW $75+$ Harmony (research) in 2017, the following number of weeds was detected: - one-year-old single-seeded Aulnay; 6 , annual bivalve molluscs -5 , perennial grasses -1 , perennial bivalve trees - 2. In 2018, during the counting on the control, the following number of weeds was detected: - one-year mono-foster animals - 34, one-year bivalves - 72, perennial grasses -3 , perennial dicotyledons -5 , which is much more than in 2017 . When spraying Dual Gold 960 EC, BC + Bazagran, dd (standard) in 2018, the following number of weeds was detected: one-year-old one-day eaters - 8, one-year two-heifers; 9 , perennial grasses -2 , perennial bilaterials -5 . When spraying, Gesagard $500 \mathrm{FW}$, hp + Harmony 75, inc. (experiment) in 2018, the following number of weeds was detected: one-year mono-dog plants -8 , one-year two-eateries -6 , perennial grasses 3 , perennial dicotyledons -4 . As evidenced by the results of experiments for 2017 , the total the number of weeds per $1 \mathrm{~m} 2$ in the standard version is -16 pieces, and on the experimental one -14 units. In 2018, the total number of weeds per $1 \mathrm{~m} 2$ in the standard version is -24 pieces, and in the experimental one -21 pieces.

As we can see from the experiment that in 2018 the number of weed on soybeans sowings have increased but it is possible to make conclusion that using herbicides by another way is more effective than in 2017 and 2018. 